\title{
Immunohistochemical Localisation of Epidermal Growth Factor, Transforming Growth Factor $\alpha$ and EGF Receptor during Organogenesis of the Murine Hypophysis in vivo
}

\author{
By \\ Yasutomo IWAI-LIAO, Shunji KUMABE, Masaki TAKEUCHI and \\ Yoshikage HIGASHI \\ Department of Oral Anatomy, Osaka Dental University, 8-1 Kuzuhananazono-cho, Hirakata-shi, Osaka 573-1121, \\ Japan \\ - Received for Publication, July 24, 1999 - \\ Key Words: EGF, TGFa, EGFR, Pituitary gland, Foetus, Mouse

\begin{abstract}
Summary: In previous study of melanocyte-stimulating hormone (MSH) cell development in the proliferating pars intermedia, which is in close apposition to the presumptive pars nervosa, no direct cell-to-cell contact was found between the boundary neurohypophyseal pituicytes (PIC), adenohypophyseal precursor stem cells (PSC) and the related diencephalic mesenchymal cells. Here, we have used immunohistochemistry to examine cytokine expression in the development of the hypophysis during foetal stages II-IV. Light and confocal laser scanning microscopy indicated diffuse expression of both TGF $\alpha$ and EGF in the hypophysis at different foetal stages. While no findings indicative for temporary changes of TGF $\alpha$ and EGF patterns were found in the foetal hypophysis, a temporary increment of EGF molecules was distinct in the diencephalic mesenchyme at stages III and IV. On the other hand, light microscopy intensively immunolocalised EGFR in the adenohypophysis and neurohypophysis at different developmental stages. Immunoreactivity of EGFR in the cytoplasm and nucleus suggested active proliferative events in the PIC and PSC of stages II-IV mouse pituitaries.
\end{abstract}

We previously detected active cell turnover with programmed cell death in the presumptive adenohypophysis (AP) and neurohypophysis (NP) and their associated cephalic mesenchyme during murine hypophysis development. The transmission electron microscopic (TEM) study suggested that signal transduction between the AP and NP via the extracellular matrix (ECM) might initiate the differentiation of melanocyte-stimulating hormone (MSH) cells in the presumptive pars intermedia at the late mid-foetal stage (Han et al., 1998).

Epidermal growth factor (EGF) and transforming growth factor alpha (TGF $\alpha$ ), which both act via the EGF receptor (EGFR), are multivalent cytokines which control cell proliferation, differentiation and ECM biosynthesis of both the epithelium and mesenchymal cells (Nexo et al., 1980; Todaro et al., 1980; Adamson et al., 1981; Yoneda \& Pratt, 1981; Cohen et al., 1982; Adamson, 1983; Cohen, 1986; Abbott et al., 1988). Recently, the EGFR was also localised to various normal human epithelial tissues, which were categorised according to the intensity and pattern of EGFR expression
(Damjanov et al., 1996).

Apoptosis of medial edge epithelial (MEE) cells is presumed to be essential for the fusion of the bilateral secondary palatine shelves (Taniguchi et al., 1995). A study on murine palatogenesis found that excess exogenous EGF/TGF $\alpha$ caused inhibition of cell death that induces cleft palate due to downregulation of the EGFR (Adams \& Warshaw, 1982). Another study observed that loss of expression of EGF, TGF $\alpha$ and their related receptors may initiate cell death, while epithelia which continuously produce TGF $\alpha$ differentiates stratified squamous keratinising epithelia (Pratt, 1987). Strong TGF $\alpha$ expression was co-localised with sparse EGF expression in the developing palate of murine foetuses, and strong TGF $\alpha$ and EGFR expression was observed at the degenerative medial MEE remnants during palatogenesis (Abbott et al., 1988; Dixon et al., 1991). Therefore, TGF $\alpha$ appears to play an important role in the degeneration and epithelial-mesenchymal transformation of the MEE region (Ferguson, 1988; Dixon et al., 1991). Several studies implicated TGF $\alpha$ as the embryonic homo- 
logue of EGF, since it was usually found in the same locations as EGFR, however a more recent study has demonstrated similar patterns of EGF, TGF $\alpha$ and EGFR expression during morphogenesis of the murine primary palate (Nexo et al., 1980; Twardzik et al., 1982; Marquardt et al., 1984; Twardzik, 1985; Freemark \& Comer, 1987; Iamaroon et al., 1996).

Direct contact occurring between the Rathke's pouch stomodaeal epithelium, diencephalic downgrowth neuroepithelium and surrounding mesenchyme are thought to be important factors in the induction of the pituitary organogenesis (Thompson \& Trimble, 1976; Ikeda et al., 1988; Stefanovi'c et al., 1993). In the present study, we localised EGF, TGF $\alpha$ and EGFR expression in the developing murine hypophysis by immunohistochemistry to determine their temporo-spatial expression during determination and differentiation of this structure.

\section{Materials and Methods}

Foetuses of Slc: ICR SPF mice (SLC, Tokyo, Japan) were removed from the uterus at 9 to 15 days from insemination following the Guidelines for Animal Experimentation at Osaka Dental University. The day the vaginal plug was observed was designated to be the gestational day 0 . The development of the foetal hypophysis was divided into four stages (stages I-IV) paralleling other previous studies (Thompson \& Trimble, 1976; Stoeckel et al., 1979; Ikeda \& Yoshimoto, 1991; Kaufman, 1992; Han et al., 1998; Hashimoto et al., 1998; Sasaki \& Nishioka, 1988). In the present study, stage II (gestational days 9-10) foetuses and the head portions of stage III (gestational days 11-12) and stage IV (gestational days 13-15) samples were trimmed into blocks and fixed by immersion with Carnoy's solution and embedded in paraffine following conventional methods. Serial sagittal $2-5 \mu \mathrm{m}$ sections of the middle portion of the head were cut using stainless steel knives mounted on an AS-500 Universal Microtome (Anglia Scientific, Cambridge, UK).

\section{Light Microscopy (LM)}

The specimens were deparaffinised and examined mainly with Ultra Vision Mouse Tissue Detection System Anti-mouse HRP/DAD (Ready-To-Use) kit (Lab Vison, CA, USA) and anti-mouse antiEGF monoclonal antibody (Monosan, Uden, The Netherlands) for detection of EGF. Endogenous peroxidase and background non-specific reactions were blocked with Hydrogen Peroxide Block and Ultra V Block following the manufacturer's in- structions, respectively. Reactive Igs were blocked using Rodent Block, and the endogenous biotin was blocked with Avidin D blocking solution and Biotin blocking solution using a Blocking Kit (Vector Lab, CA, USA). The specimens were reacted with the anti-mouse anti-EGF monoclonal antibody (primary antibody; $5 \mu \mathrm{g} / \mathrm{ml}, 2 \mathrm{~h}$, room temp), biotinylated goat anti-mouse antibody (secondary antibody; $15 \mathrm{~min}$, room temp) and then treated with streptavidin peroxide $(15 \mathrm{~min}$, room temp). Subsequently, the DAB substrate-treated specimens were stained with DAB chromogen and counter-stained with methylgreen. The specimens were mounted on slide glasses, embedded in Permount (Fisher Scientific, New Jersey, USA), examined and photographed under an Olympus Vanox-S light microscope (Olympus, Tokyo, Japan).

Expression of the TGF $\alpha$ and EGFR of the developing hypophysis was examined with an anti-rat anti-TGF $\alpha$ polyclonal antibody (primary antibody; Biogenesis, Poole, UK) and anti-EGFR polyclonal antibody (primary antibody; Santa Cruz Biotech, CA, USA) using the ImmunoCruz Staining System (Santa Cruz Biotech, CA, USA). The endogenous peroxidase and non-specific reactions were blocked by peroxide block and serum block, respectively. After blockage, the specimens were further treated with Avidin D blocking solution and Biotin blocking solution, and were then reacted with the antiTGF $\alpha$ and anti-EGFR antibodies. The specimens were reacted with biotinylated secondary antibody and HRP-streptavidin complex, stained by a mixture of DAB Chromogen, peroxidase substrate and substrate buffer, and then were counter-stained by methylgreen and prepared for LM.

\section{Confocal Laser Scanning Microscopy (CLSM)}

For localisation of EGF and TGF $\alpha$ molecules using CLSM, some specimens were treated with an anti-EGF antibody (primary antibody; Monasan, Uden, The Netherlands) and an anti-TGF $\alpha$ antibody (primary antibody; Biogenesis, Poole, UK), respectively. The specimens were subsequently treated with biotinylated gout anti-mouse antibody (secondary antibody) for detection of EGF using an UltraVision Mouse Tissue Detection System Anti-mouse HRP/DAD (Ready-To-Use) kit (Lab Vision, CA, USA), as well as with goat anti-rabbit antibody (secondary antibody) for detection of the TGF $\alpha$ using the ImmunoCruz Staining System (Santa Cruz Biotech, CA, USA). Then specimens were reacted with streptavidin, Alexa 488 conjugate (fluorescence wavelength $519 \mathrm{~nm}$; Molecular Probes, Oregon, USA), and the RNA in the tissue was digested by RNase A (Amresco, Ohio, USA). Subsequently, the specimens were counter-stained 
with Propidium Iodide DNA staining (PI; fluorescence wavelength $615 \mathrm{~nm}$; Molecular Probes, Oregon, USA) for identification of the cell nucleus. They were mounted in Vectashield Mounting Medium (Vector Lab, CA, USA), and were then analysed using an Olympus personal Fluoview CLSM (Argon ion laser, excitation wave length $488 \mathrm{~nm}$ (CH1); Green $\mathrm{HeNe}$ ion laser, excitation wave length $543 \mathrm{~nm}(\mathrm{CH} 2)$; using $\mathrm{CH} 1$ : BA510IF \& BA530IF, CH2: BA590 \& BA565IF filters; Fluoview ver. 2.0.32; OS: MS Windows NT Workstation Ver. 4.0; Olympus, Tokyo, Japan).

\section{Results}

The pattern of expression of TGF $\alpha$ in the developing hypophysis was relatively unchanged at all stages (stages II-IV) by LM. TGF $\alpha$ was diffusely found in the developing AP, NP and in the associated diencephalic mesenchyme, and there were no apparent temporal changes in TGF $\alpha$ expression (Figs. 1 and 2). EGF immunoreactivity in the developing hypophysis was weak but also relatively unchanged at all stages. Weak reactivity was seen on the basement membrane and cells in the NP and AP, with strong expression evident in the associated diencephalic mesenchyme (Figs. 3 and 4). EGF expression increased with time in the diencephalic mesenchyme (Fig. 4). EGFR immunoreactivity was seen in the developing hypophysis and surrounding mesenchyme at all stages examined (Figs. 5 and 6). Specific EGFR reactivity was seen in the pars distalis at stage IV, and also in the nucleus of actively proliferating NP and AP cells (Figs. 5 and 6).

CLSM of specimens labelled with streptavidin, Alexa 488 conjugate and PI using the LsAB method showed intense fluorescence $(\mathrm{CH} 1)$ specific for EGF and TGF $\alpha$ in the presumptive NP and AP at proliferative stage II (Figs. 7a-8). Similar patterns of expression of TGF $\alpha$ and EGF was seen in the pituitary at stages III-IV (Figs. 8-14). Consistent with LM, CLSM showed no marked temporal changes in TGF $\alpha$ or EGF expression in the proliferating hypophysis. Histology of the developing hypophysis showed that the NP and AP at stages III-IV were separated with the surrounding diencephalic mesenchyme and capillaries (Figs. 8-10). In addition, specific cell-to-cell contacts across a thin immunoreactive layer were seen between the developing NP and pars intermedia at stage IV (Figs. 10 and 13).

\section{Discussion}

A previous study observed that the diencephalic mesenchymal tissue invaded and thereby cleaved the developing AP into many lobules (Hashimoto et al., 1998). Subsequent penetration of vascular elements from the hypophyseal portal system into the foetal pars distalis was suggested to be an important determinant of all secretory cell types in the pituitary (Thompson \& Trimble, 1976). In addition, a three-dimensional histological study of the developing human pituitary showed that AP cells with closer physical contact to the developing NP have increased epithelial characteristics, while cells in the pars distalis which are less proximal to the NP differentiate into endocrine cells earlier (Ikeda et al., 1988). In contrast, one study found that ACTH-positive cells have different staining patterns in the foetal and adult pars distalis and pars intermedia, and have specific temporal patterns of expression in different sites of the pituitary (Perry et al., 1985). However, no selective increase in ACTH-like activity in the anterior pituitary at late gestation was observed using bioassay and radioimmunoassay methods (Fora et al., 1996). Another study found that isolated ACTH-cells first appeared at the boundaries where pars intermedia cells migrated towards the pituitary anterior lobe (Altukhova et al., 1983). Other studies have stressed that differentiation of MSH cells is evident before vascularisation and innervation, or folliculation of the pars intermedia (Chatterjee, 1975; Perry et al., 1981; 1982). In a previous TEM study, we observed that the proliferating AP was heavily lobulated, but did not differentiate into endocrine cell types in the mid-foetal stage. In addition, we identified the first appearance of MSH cells in the presumptive pars intermedia (Han et al., 1998).

A recent study reported that several transcription factors that regulate the determination of specific types and organs were expressed in a ventralto-dorsal gradient at different stages in pituitary organogenesis (Treier et al., 1998). Various factors in the pituitary-specific transcriptional cascade that regulates cell proliferation, differentiation and maturation have been identified (Rodriquez \& Jolin, 1993; Kimura et al., 1996; Parks et al., 1997; Sheng et al., 1997; de la Hoya et al., 1998; WatkinsChow \& Camper, 1998). In sits hybridisation showed a decrease in p75 nerve growth factor receptor (NGFR) expression in the Rathke's pouch and pars intermedia during the differentiation of pituitary cell types (Ramaekers et al., 1997). The $\mathrm{S}-100$ acidic calcium-binding protein is co-localised with vimentin in melanotropes coinciding with the onset of dopaminergic innervation and morpho- 
logical changes in glial-like cells of the rat pars intermedia (Sands et al., 1995). Furthermore, morphological changes in glial-like cells of the pars intermedia is associated with subsequent changes in protein expression (Gary et al., 1995).

The growth and functional differentiation of the adrenal gland is induced by EGF, and inhibited by a glucocorticoid negative feedback mechanism (Coulter et al., 1996). In addition, both EGF and fibroblast growth factor-4 (FGF-4) inhibit apoptosis and thereby regulate proliferation and differentiation of dental tissues (Vaahatokari et al., 1996). In the present study, we localised weak EGF but intense TGF $\alpha$ immunoreactivity in the mouse pituitary at different developmental stages by LM. CLSM with fluorescent antibodies clearly mapped similar distribution of EGF and TGF $\alpha$ expression in the foetal pituitary at different stages. However, neither the LM nor CLSM analyses showed evidence of any temporal changes in EGF or TGF $\alpha$ (the embryonic homologue of EGF) expression in the NP and AP (Nexo et al., 1980; Twardzik et al., 1982; Marquardt et al., 1984; Twardzik, 1985; Freemark \& Comer, 1987). In contrast, EGFR was differentially expressed in the pituitary at different stages; intense immunoreactivity was found in the pars distalis at stage IV. EGFR expression in the cytoplasm and nucleus seemed to indicate downregulation by an internalisation mechanism of EGFR and EGF-receptor complexes in the actively proliferating NP and AP cells. The results of the present study are consistent with those of our previous histological study, which indicated that the mid-foetal murine pituitary is at the active proliferation stage (Han et al., 1998).

TEM of the proliferating AP showed junctional complex in folliculo-stellate cells facing the hypophyseal cleft and zonula adherens-type junctions between the AP cells (Herbert, 1979; Han et al., 1998). A recent TEM study which showed substance $\mathbf{P}$ immunoreactivity in the anterior pituitary suggested that the presence of synaptoid contacts is responsible for cross-talk between the AP glandular cells of the rat (Liu \& Ju, 1998). Observation of intracellular diffusion and freeze-fracture TEM of the cell surface in the pituitary gland have shown a dense cellular network connected by functional gap junction-mediated cell-to-cell communication among agranular folliculo-stellate cells which differentiate into granular and chromophilic cells (Kurono, 1996; Morand et al., 1996; Munari-Silem \& Rousset, 1996; Guerineau et al., 1997; Soji et al., 1997). However, the development of gap junctions has been reported to be induced by certain paracrine interactions in the pituitary gland (Kurono, 1996; Schwartz et al., 1998). We previously found that the close cell-to-cell contact sites between the proliferating NP and AP were actually interposed with a thin layer of ECM (Stefanovi'c et al., 1993; Han et al., 1998). To elucidate intercellular communication and signal transduction events which initiate the differentiation of MSH cells in the pars intermedia, further immunohistochemical study is needed to localise structures and inducers related to cell-to-cell contacts.

\section{Acknowledgements}

The study was performed using the Laboratory Animal and Morphological Research Facilities in the Institute of Dental Research, Osaka Dental University. The study was supported by a grant-inaid from the Osaka Dental University Research Funds.

\section{References}

1) Abbott BD, Adamson ED and Pratt RM. Retinoic acid alters EGF receptor expression during palatogenesis. Development 1988; 102:853-867.

2) Adamson ED, Deller MJ and Warshaw JB. Functional EGF receptors are present on mouse embryo tissues. Nature 1981; 291:565-659.

3) Adamson ED and Warshaw JB. Down-regulation of epidermal growth factor receptors in mouse embryos. Devlop Biol 1982; 90:430-434.

4) Adamson ED. Growth factors in development. In: The biological basis of reproductive and developmental medicine. Warshaw JB (ed.), 307-336, Elsevier, New York, 1983.

5) Altukhova VI, Bukuia B and Shtark E. Differentiation of immunopositive ACTH cells in the human fetal pituitary gland. Ark Anat, Gistol i Embryol 1983; 85:50-56. (Russian)

6) Chatterjee P. Development and cytodifferentiation of the rabbit pars intermedia. I. Fetal and perinatal stages. Cell Tiss Res 1975; 164:481-501.

7) Cohen $S$, Ushiro $H$, Stoscheck $C$ and Chinkers $M$. A native 170,000 epidermal growth factor receptor-kinase complex from shed plasma membrane vesicles. J Biol Chem 1982; 257:1523-1531.

8) Cohen S. Epidermal growth factor. Biosci Reps 1986; 6:1017-1028.

9) Coulter CL, Read LC, Carr BR, Tarantal AF, Barry S and Styne DM. A role for epidermal growth factor in the morphological and functional maturation of the adrenal gland in the fetal rhesus monkey in vivo. J Clinical Endocrinol Metabolism 1996; 81:1254-1260.

10) Damjanov I, Mildner B and Knowles BB. Immunohistochemical localization of the epidermal growth receptor in normal human tissues. Lab Invest 1996; 55:588592.

11) Dixon MJ, Garner J and Ferguson MWJ. Immunolocalisation of epidermal growth factor (EGF), EGF receptor and transforming growth factor alpha (TGF $\alpha$ ) during murine palatogenesis in vivo and in vitro. Anat Embryol 1991; 184:83-91.

12) de la Hoya M, Vila V, Jimenez $O$ and Castrillo JL. Ante- 
rior pituitary development and Pit-1/GHF-1 transcription factor. Cell Mol Life Sci 1998; 54:1059-1066.

13) Fora MA, Valego NK, Lively MO, Castro MI and Rose JC. ACTH-like bioactivity and immunoactivity in fetal lamb pituitaries at 0.65 and 0.95 gestation. Reproduction, Fertility, \& Development 1996; 8:195-201.

14) Freemark $M$ and Comer $M$. Epidermal growth factor (EGF)-like transforming growth factor (TGF) activity and EGF receptors in ovine fetal tissues: possible role for TGF in ovine fetal development. Pediatr Res 1987; 22:609-615.

15) Furguson MWJ. Palate development. Development (suppl) 1988; 103:41-60.

16) Gary KA, Sands SA and Chronwall BM. Glial-like cells of the pituitary intermediate lobe change morphology and shift from vimentin to GFAP expression during development. Intl J Dev Neurosci 1995; 13:555-565.

17) Guerineau NC, McKinney RA, Debanne D, Mollard P and Gahwilier BH. Organotypic cultures of the rat anterior pituitary: morphology, physiology and cell-to-cell communication. J Neurosci Methods 1997; 73:169-176.

18) Han KS, Iwai-Liao Y and Higashi Y. Early organogenesis and cell contact in the proliferating hypophysis of the developing mouse. Okajimas Folia Anat Jpn 1998; 75:97-109.

19) Hashimoto $H$, Ishikawa and Kusakabe M. Three-dimensional analysis of the developing pituitary gland in the mouse. Devlop Dynamics 1998; 212:157-166.

20) Herbert DC. Intercellular junctions in the rhesus monkey pars distalis. Anat Rec 1979; 195:1-6.

21) Iamaroon A, Tait B and Diewert VM. Cell proliferation and expression of EGF, TGF $\alpha$, and EGF receptor in the developing primary palate. J Dent Res 1996; 75:1534-1539.

22) Ikeda $H$, Suzuki J, Sasano $N$ and Niizuma $H$. The development and morphogenesis of the human pituitary gland. Anat Embryol 1988; 178:327-336.

23) Ikeda $\mathrm{H}$ and Yoshimoto $T$. Immunohistological distribution of simple-epithelial-type keratins and other intermediate filament proteins in the developing human pituitary gland. Cell Tissue Res 1991; 266:59-64.

24) Kaufman MH. The atlas of mouse development. Academic Press, London, 1992.

25) Kimura S, Hara $Y$, Pineau T, Fernandez-Salguero $P$, Fox $\mathrm{CH}$, Ward JM and Gonzalez FJ. The T/ebp null mouse: thyroid-specific enhancer-binding protein is essential for the organogenesis of the thyroid, lung, ventral forebrain, and pituitary. Genes Dev 1996; 10:60-69.

26) Kurono C. Intercellular communication within rat anterior pituitary gland: VI. Development of gap junctions between folliculo-stellate cells under the influence of ovariectomy and sex steroids in the female rat. Anat Rec 1996; 244:366373.

27) Liu YY and Ju G. Synaptoid contacts between gland cells of the anterior pituitary of the rat. Anat $\operatorname{Rec} 1998$; 251:181-184.

28) Marquardt H, Hunkapiller MW, Hood LE and Todaro GJ. Rat transforming growth factor type 1: structure and relation to epidermal growth factor. Science 1984; 223:10791082 .

29) Morand I, Fonlupt P, Guerrier A, Trouillas J, Calle A, Remy C, Rousset B and Munari-Silem Y. Cell-to-cell communication in the anterior pituitary: evidence for gap junction-mediated exchanges between endocrine cells and folliculo-stellate cells. Endocrinol 1996; 137:3356-3367.

30) Munari-Silem $Y$ and Rousset B. Gap junction-mediated cell-to-cell communication in endocrine glands - molecular and functional aspects: a review-. Eu J Endocrinol 1996; 135:251-264.

31) Nexo E, Hollenberg MD, Figueroa A and Pratt RM. De- tection of epidermal growth factor-urogastrone and its receptor during fetal mouse development. Proc Nat Acad Sci USA 1980; 77:2782-2785.

32) Parks JS, Adess ME and Brown MR. Genes regulating hypothalamic and pituitary development. Acta Paediatrica 1997; 423(suppl):28-32.

33) Perry RA, Robinson PM and Ryan GB. Ultrastructure of the pars intermedia of the adult sheep hyponhysis. Cell Tissue Res 1981; 217:211-223.

34) Perry RA, Robinson PM and Ryan GB. Ultrastructure of the pars intermedia of the developing sheep hypophysis. Cell Tissue Res 1982; 224:369-381.

35) Perry RA, Mulvoque HM, McMillen IC and Robinson PM. Immunohistochemical localization of ACTH in the adult and fetal sheep pituitary. J Develop Physiol 1985; 7:397404.

36) Pratt RM. Role of epidermal growth factor in embryonic development. In: Current topics in developmental biology. Vol 22. The molecular and developmental biology of keratins. Sawyer RH (ed.), 175-193, Academic Press, New York, 1987.

37) Ramaekers D, Proesmans $M$ and Denef $C$. Expression of the low-affinity p75 nerve growth factor receptor in the developing rat pituitary gland. Neurochem Res 1997; 22:1353-1357.

38) Rodriquez $M$ and Jolin T. Triiodothyronine receptor complex in developing rat brain and pituitary. Am J Physiol 1993; 264(5 Pt 1):E804-809.

39) Sands SA, Gary KA and Chronwall BM. Transient expression of S-100 by melanotropes of the rat pituitary intermediate lobe during development. International $\mathbf{J}$ Develop Neurosci 1995; 13:567-576.

40) Sasaki F and Nishioka S. Fetal development of the pituitary gland in the beagle. Anat Rec 1998; 251:143-151.

41) Schwartz J, Van de Pavert S, Clarke I, Rao A, Ray D and Vrana K. Paracrine interactions within the pituitary gland. Ann New York Acad Sci 1998; 839:239-243.

42) Sheng HZ, Moriyama K, Yamashita T, Li H, Portter SS, Mahon KA and Westphal H. Multistep control of pituitary organogenesis. Science 1997; 278(5344):1809-1812.

43) Soji T, Mabuchi Y, Kurono $C$ and Herbert DC. Folliculostellate cells and intercellular communication with the rat anterior pituitary gland. Microsc Res Tech 1997; 39:138149.

44) Stefanovi'c V, Saraga Babi'c M and Wartiovaara J. Cell contacts in early human pituitary development. Acta Anat 1993; 148:169-175.

45) Stoeckel ME, Hindelang-Gertner C and Porte A. Embryonic development and secretory differentiation in the pars tuberalis of the mouse hypophysis. Cell Tissue Res 1979: 198: $465-476$.

46) Taniguchi K, Sato N and Uchiyama Y. Apoptosis and heterophagy of medial edge epithelial cells of the secondary palatine shelves during fusion. Arch Histol Cytol 1995: 191-203.

47) Tompson SA and Trimble III JJ. The embryological development and cytodifferentiation of the pars distalis of the golden hamster (Mesocricetus auratus). A light and electron microscopic study. Anat Embryol 1976; 150:7-17.

48) Todaro GJ, Fryling $C$ and De Larco JE. Transforming growth factors produced by certain human tumor cells: polypeptides that interact with epidermal growth factor receptors. Proc Natl Acad Sci USA 1980; 77:5258-5262.

49) Treier M, Gleiberman AS, O'Connell SM, Szeto DP. McMahon JA, McMahon AP and Rosenfeld MG. Multistep signaling requirements for pituitary organogenesis in vivo. Genes Develop 1998; 12:1691-1704. 
50) Twardzik DR, Ranchalis JE and Todaro GJ. Mouse embryonic transforming growth factors related to those isolated from tumor cells. Cancer Res 1982; 42:590-593.

51) Twardzik DR. Differential expression of transforming growth factors $\alpha$ during prenatal development of the mouse. Cancer Res 1985; 45:5413-5416.

52) Vaahatokari A, Åberg T and Thesleff I. Apoptosis in the developing tooth: association with an embryonic signaling center and suppression by EGF and FGF-4. Development 1996; 122:121-129.

53) Watkins-Chow DE and Camper SA. How many homeobox genes does it take to make a pituitary gland? Trends in Genetics 1998; 14:284-290.

54) Yoneda $T$ and Pratt RM. Mesenchymal cells from the human embryonic palate are highly responsive to epidermal growth factor. Science 1981; 213:563-565.

\section{Abbreviations used in Figs. 1-14}

$\begin{array}{llll}\text { A } & \text { Presumptive adenohypophysis } & \text { PD } & \text { Presumptive pars distalis } \\ \text { CLSM } & \text { Confocal laser scanning microscopy } & \text { TGF } \alpha & \text { Transforming growth factor } \alpha \\ \text { EGF } & \text { Epidermal growth factor } & \text { S2 } & \text { Developmental stage II } \\ \text { LM } & \text { Light microscopy } & \text { S3 } & \text { Developmental stage III } \\ \text { N } & \text { Presumptive neurohypophysis } & \text { S4 } & \text { Developmental stage IV }\end{array}$

\section{Explanation of Figures}

\section{Plate I}

Fig. 1. Light microscopy (LM) showing immunolocalisation of TGF $\alpha$ in stage II (S2) developing murine hypophysis composed of the diencephalic downgrowth (the presumptive neurohypophysis: N) and Rathke's pouch (the presumptive adenohypophysis: A).

Fig. 2. TGF $\alpha$ expression at stage IV (S4) hypophysis observed by LM. No temporal change of TGF $\alpha$ expression is evident. The proliferating pars distalis (PD) of $\mathrm{A}$ is deeply invaginated with the diencephalic mesenchyme and its associated capillaries (arrows).

Fig. 3. LM shows weak EGF expression in the $\mathrm{N}$ and $\mathrm{A}$ of the $\mathrm{S} 2$ developing hypophysis.

Fig. 4. Intense EGF expression is found in the diencephalic mesenchyme of the stage III (S3) hypophysis, while weak EGF reactivity is observed in the proliferating hypophysis, in particular at the basement membrane and cell membrane facing the hypophyseal cleft. 

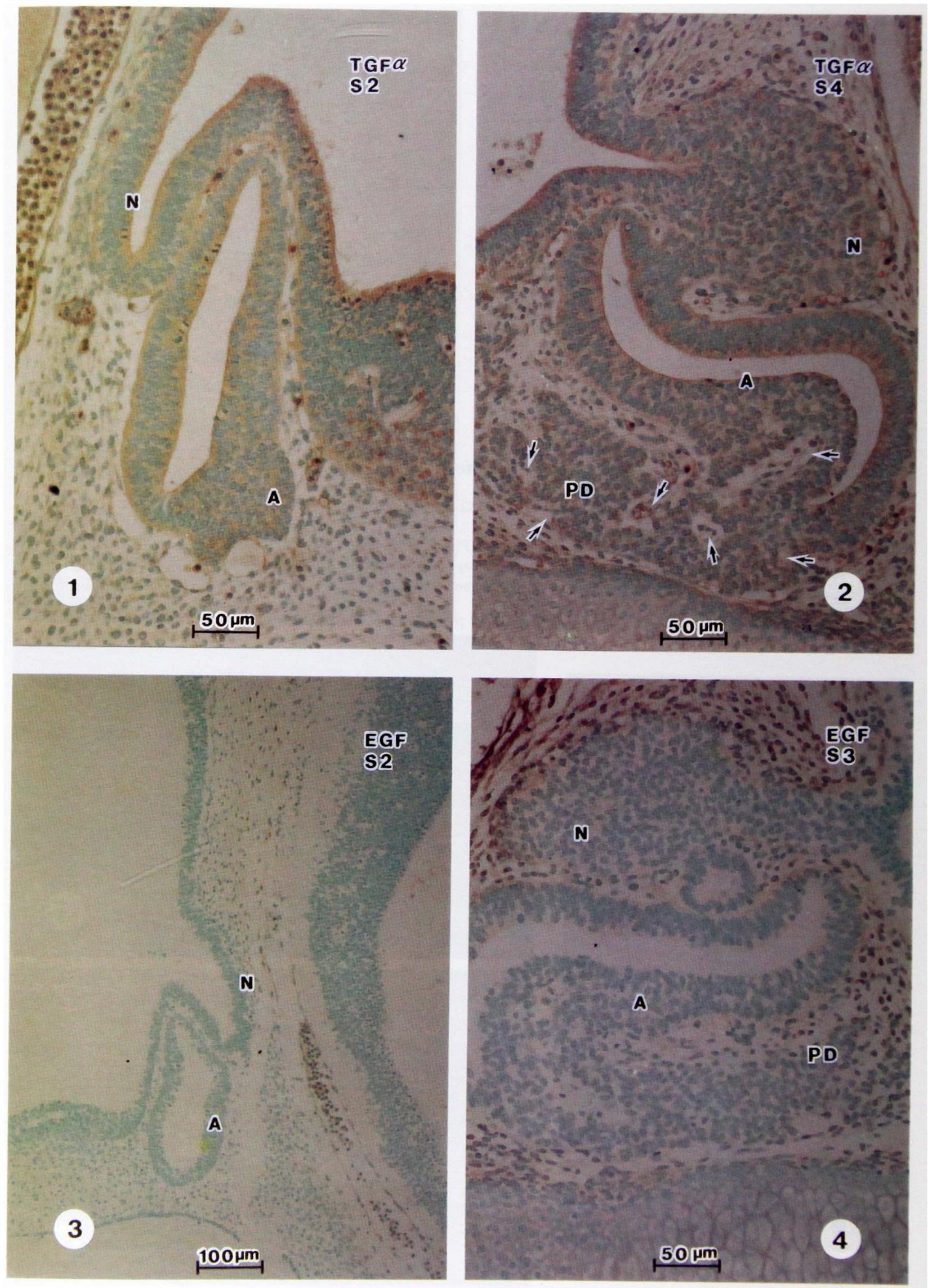


\section{Plate II}

Fig. 5. LM mapped EGFR to the presumptive $\mathrm{N}$ and $\mathrm{A}$ at the $\mathrm{S} 2$ developmental stage. The EGFR is also immunolocalised in cell nuclei of the proliferating hypophysis.

Fig. 6. EGFR is expressed in proliferating cells of the N, A and PD of a developing S3 hypophysis (LM).

Fig. 7. Confocal laser scanning microscopy (CLSM) of TGF $\alpha$ expression in an S2 specimen. 7a. TGF $\alpha$ expression in both the N, $\mathrm{A}$ and the related tissues. $7 \mathrm{~b}$. Higher magnification of the same specimen clearly shows specific TGF $\alpha$ expression in the proliferating hypophysis.

Fig. 8. CLSM showing similar EGF and TGF $\alpha$ expressions (Fig. 7b) in the foetal S2 hypophysis. Arrows indicate that the N and A are separated by a thin layer of diencephalic mesenchyme containing capillaries. 

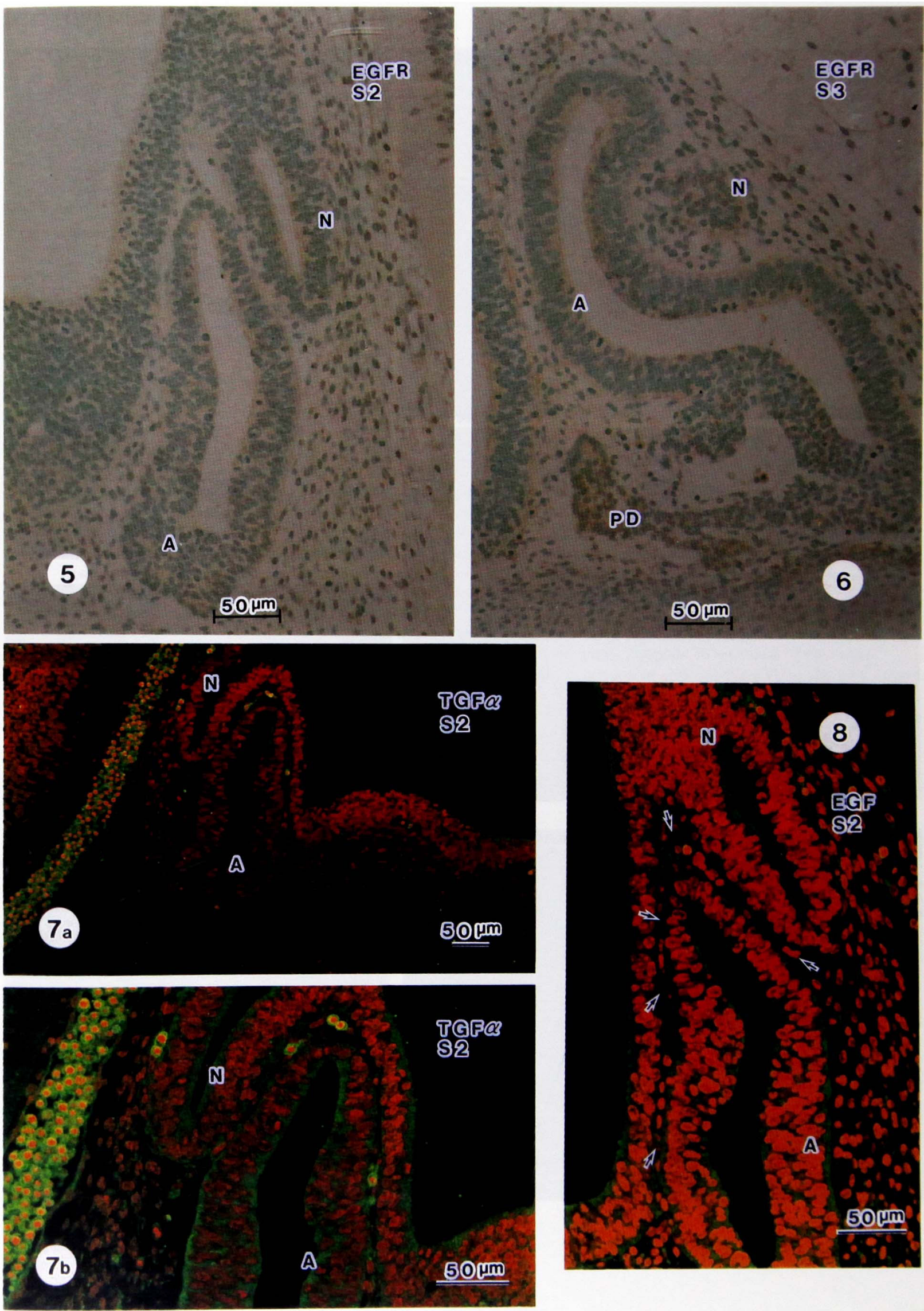


\section{Plate III}

Fig. 9. While LM only showed weak EGF immunoreactivity (Fig. 4), CLSM clearly identifies EGF expression in a proliferating S3 hypophysis.

Fig. 10. EGF expression in cells of N, A and proliferating PD of an S4 hypophysis by CLSM. Arrowheads indicate that projections from $A$ is very closely associated with $N$, but they are actually separated by the basement membrane, which shows EGF immunoreactivity.

Fig. 11. CLSM of another S4 specimen. Photo also demonstrates that the A bulged with a large projection, which extends towords the proliferating $\mathrm{N}$. However, the $\mathrm{N}$ and $\mathrm{A}$ are separated by a thin layer of diencephalic mesenchyme (arrowheads).

Fig. 12. TGF $\alpha$ expression in an S3 specimen viewed under CLSM. TGF $\alpha$ molecules are widely and strongly expressed in the N, A and surrounding tissues.

Fig. 13. Similar to findings in the S3 hypophysis (Fig. 12), TGF $\alpha$ expression is distinctly localised in the N, A and PD in S4 specimens using CLSM. Arrowheads indicate projections from the presumptive pars intermedia.

Fig. 14. CLSM of TGF $\alpha$ expression in another S4 specimen. An arrowhead also shows the intimate relationship between the $\mathrm{N}$ and $\mathrm{A}$. 

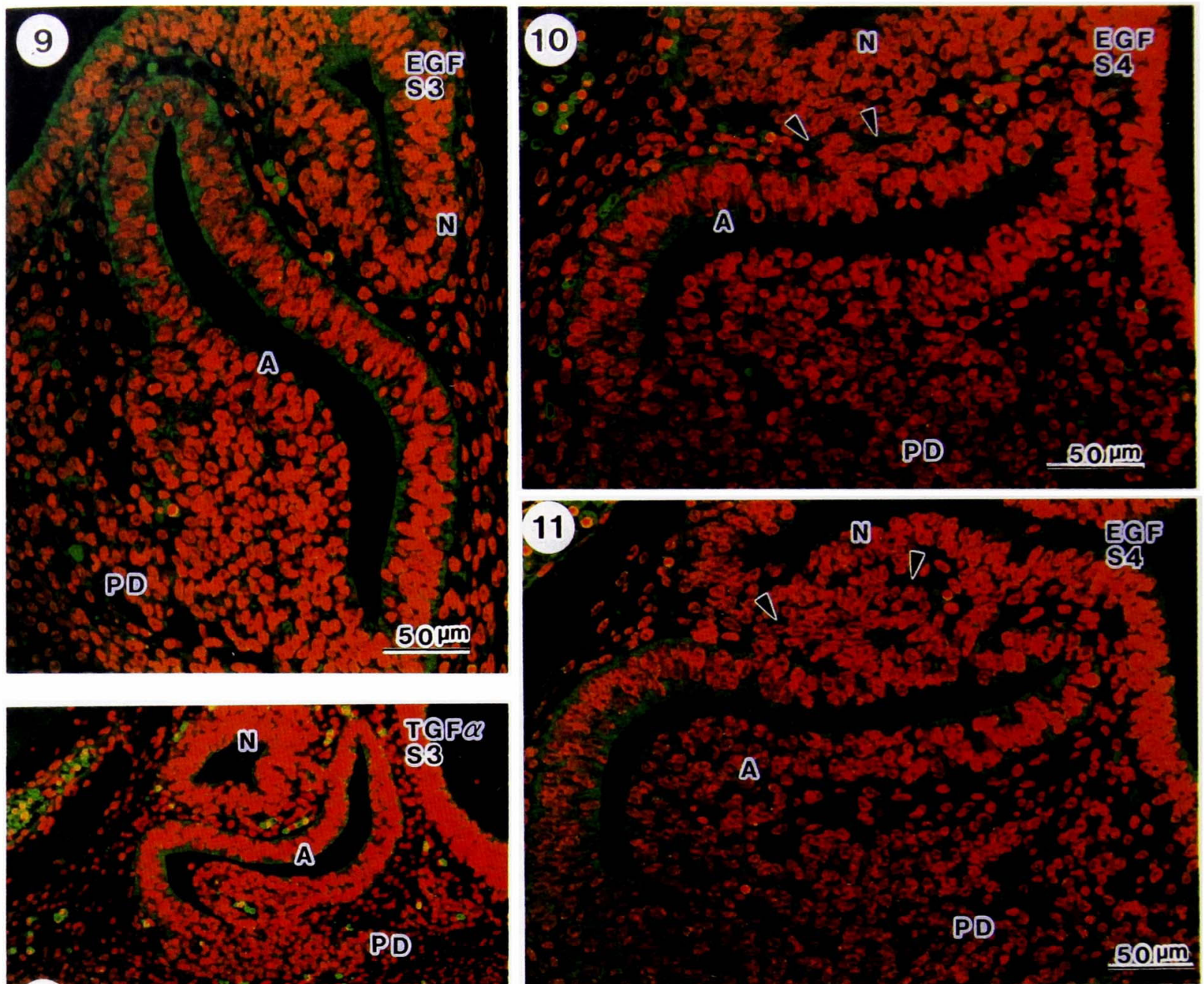

\section{2}
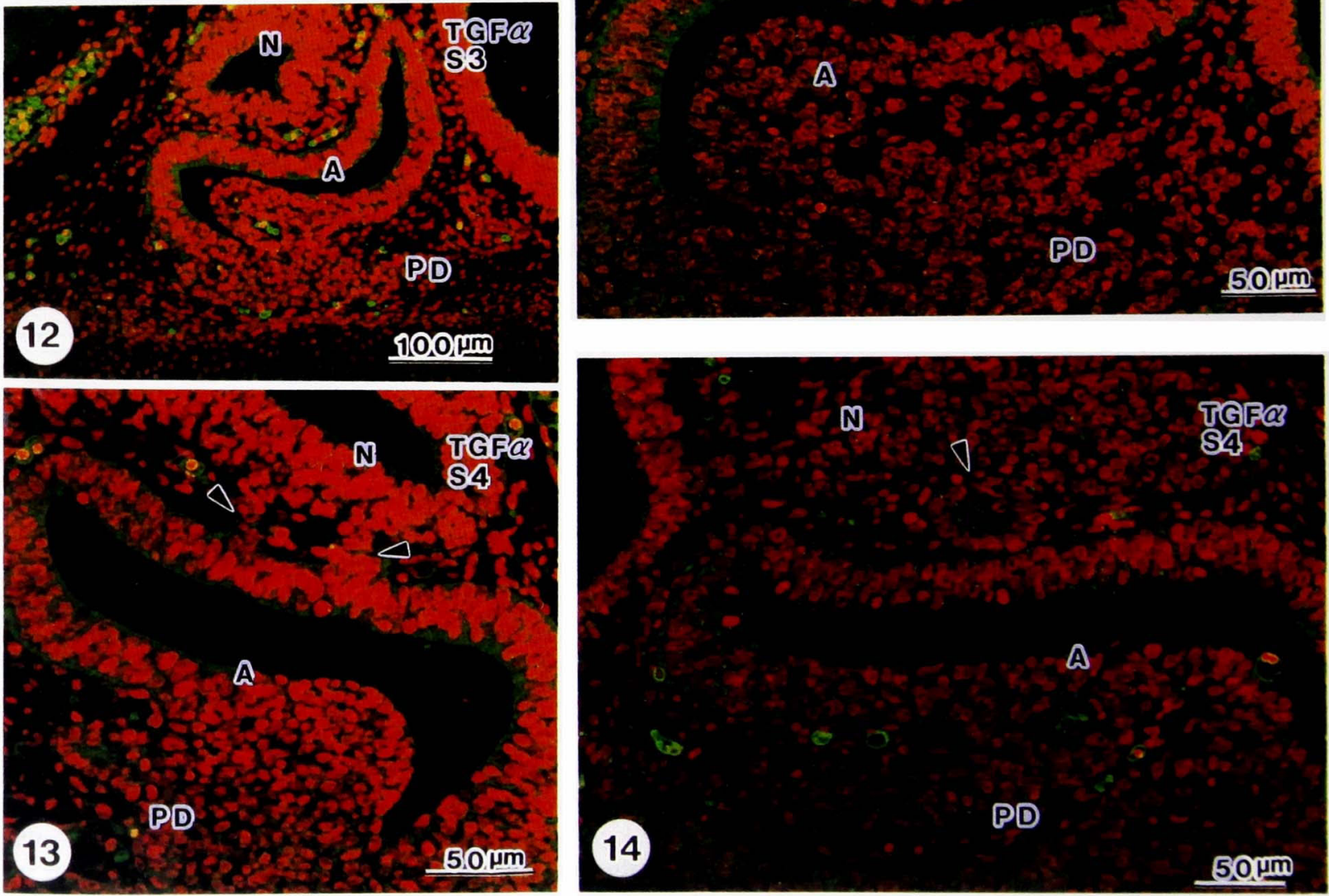